\title{
Cem Anos de Solidão: Algumas Chaves de Leitura
}

\author{
Cien Años de Soledad: Algunas Llaves de Lectura \\ One Hundred Years of Solitude: Some Keys to the Reading
}

\author{
Daniel Castelo Branco Ciarlini ${ }^{1}$
}

\begin{abstract}
Resumo
Demonstrar vieses de leitura da obra Cem anos de solidão (1967), de Gabriel García Márquez, é o que se propõe neste artigo. Para isso, explora-se o modo como o escritor utilizou na fábula contrapontos, inversões e oposições, construídas a fim de operacionalizar, no entrelace dos tempos histórico e mítico, certo ar de encantamento comum ao estilo em que se inscreve o livro, o realismo maravilhoso. Dessa forma, foi possível identificar dois níveis de trabalho em Márquez: um externo, que lida diretamente com a apreensão do leitor; e um interno, relacionado à conduta de suas próprias personagens. Dialoga-se, aqui, especialmente, com os textos de Chiampi (2012), quando esta discute o realismo maravilhoso como gênero, Josefina Ludmer (1972) e Ángel Rama (1987), cujas análises permitem a compreensão dos jogos opostos internos da obra.
\end{abstract}

Palavras-Chave: Gabriel García Márquez; realismo maravilhoso; Cem anos de solidão.

\section{Resumen}

Demostrar vieses de lectura de la obra Cien años de soledad (1967), de Gabriel García Márquez, es lo que se propone en este artículo. Para ello, se explora el modo en que el escritor utilizó en la fábula contrapuntos, inversiones y oposiciones, construidas a fin de dotar, en el entrelazado de los tiempos histórico y mítico, cierto aire de encantamiento - común al estilo en que se inscribe el libro, realismo maravilloso. De esa forma, fue posible identificar dos niveles de trabajo en Márquez: un externo, que lidia directamente con la aprehensión del lector; y un interno, relacionado con la conducta de sus propios personajes. En el caso de Chiampi, cuando se discute el realismo maravilloso como género, Josefina Ludmer (1972) y Ángel Rama (1987), cuyas análisis permiten la comprensión de los juegos opuestos internos de la obra.

Palabras claves: Gabriel García Márquez; realismo maravilloso; Cien años de soledad.

\begin{abstract}
Presenting directions of reading for One hundred years of solitude (1967), is what is proposed in this article. In order to do so, the way in which the writer used counterpoints, inversions and oppositions in the fable is explored, to prepare and show, with the mixture of historical and mythical times, an air of enchantment common to the style in which the book is written, wonderful and realism. This way, it was possible to identify two levels of work in Márquez: an external one, which deals directly with the reader's apprehension; and an internal one, related to the conduct of its own personages. This is especially the case with Chiampi (2012), when she discusses the wonderful and the realism as a unique genre, Josefina Ludmer (1972) and Ángel Rama (1987), whose analyzes allow an understanding of the opposite internal games of the book.
\end{abstract}

Keywords: Gabriel García Márquez; wonderful realism; One hundred years of solitude.

\footnotetext{
${ }^{1}$ Doutorando em Estudos da Literatura; Universidade Federal do Rio Grande do Sul - UFRGS; Porto Alegre, Rio Grande do Sul, Brasil; danielcastellobranco@hotmail.com
} 


\section{0 entrelace de dois tempos}

Das tantas possibilidades para se interpretar Cem anos de solidão (1967), de Gabriel García Márquez, uma delas talvez esteja na leitura dos dois tempos que se entrelaçam na narrativa: o mítico e o histórico. A partir deles, uma série de conjunturas vai se sobrepondo ao tecido da fábula, a expor as características que põe ao texto o tom alegórico e certo ar de encantamento, como exige o realismo maravilhoso. Sua acepção, portanto, invoca, necessariamente, uma tradução, cujas chaves, ironicamente, são apresentadas pelo próprio narrador ao longo do trabalho.

O tempo mítico, por exemplo, vem atrelado ao tempo histórico, e logo nas primeiras linhas do romance expõe o caráter cíclico que a narrativa haverá de ser trabalhada: "Muitos anos depois, diante do pelotão de fuzilamento, o coronel Aureliano Buendía havia de recordar aquela tarde remota em que seu pai o levou para conhecer o gelo" (MÁRQUEZ, 2016, p. 7, grifo nosso). A expressão grifada será a chave com que o autor fará uso, por meio de seu narrador, para retomar o tempo histórico do texto no foco do coronel Aureliano Buendía, não é à toa que ela se repete algumas vezes. Ademais, o tempo mítico é denunciado, ainda no primeiro parágrafo, quando o narrador, ao falar dos primeiros tempos de Macondo, anuncia: "O mundo era tão recente que muitas coisas careciam de nome, e para mencioná-las era preciso apontar com o dedo" (ibidem, p. 7). Esse tipo de construção remete ao momento mítico do "princípio", como discorre Mircea Eliade: "Através da repetição do ato cosmogônico, o momento concreto, no qual a construção tem lugar, é projetado para o tempo mítico, il illo tempore, quando ocorreu a fundação do mundo" (ELIADE, 1992, p. 25), daí a circularidade estar relacionada a "qualquer repetição de um gesto arquetípico, [que] suspende a duração, apaga o profano, e participa no tempo mítico" (ELIADE, 1992, p. 38).

Logo, e partir dessa visão cosmogônica, a citação faz referência ao Popol-Vuh, livro sagrado dos Maias, traduzido pelo romancista Miguel Ángel Asturias e pelo mexicano J. M. González de Mendonza, direto do francês, em 1927, com o título Los dioses, los héroes y los hombres de Guatemala Antigua. Para Irlemar Chiampi (2012, p. 45), a tradução e consequentemente a divulgação dessa obra "foram certamente decisivas para a noção do realismo mágico romanesco", ainda quando, no caso de Márquez, a obra, em seu segundo capítulo, se concentra em torno do poder da Palavra como formadora da matéria,

O dilema da nomeação das coisas americanas - como fator da constituição de uma linguagem romanesca propriamente hispano-americana, sem perder de vista o real 
natural e o histórico - pode ser vinculado a esse mito americaníssimo e universal da criação mágica do mundo (CHIAMPI, 2012, p. 25).

O "dilema da nomeação", por essa razão, acaba sendo uma constante em Cem anos de solidão, e sua provocação está exposta na figura de Fernanda del Carpio, quando esta lida com a linguagem de maneira enviesada, o que acarreta problemas à personagem, que recorre a uma cirurgia espiritual malograda; ou até mesmo quando sobre o povoado há a praga do esquecimento, o que exige do povo a afixação de bilhetinhos sobre objetos e coisas, explicando-lhes, inclusive, suas funções. Ambos, portanto, corroboram com a construção mítica e arquetípica, imagens que reforçam o caráter encantatório do livro. Mais ainda, ao ganhar o prêmio Nobel de Literatura, é Márquez quem relata a natureza mágica da América Latina, sendo esse tipo de realismo algo bastante comum ao cotidiano de seus concidadãos, em que "notícias fantasmagóricas da América Latina, essa pátria imensa de homens alucinados e mulheres históricas, cuja tenacidade sem fim se confunde com a lenda" (MÁRQUEZ, 2014, p. 12). Tal constatação de Márquez já o acompanhava antes mesmo do prêmio, é o que demonstra a resposta dada a Vargas Llosa no Peru em 1968, quando questionado se o seu estilo era fantástico ou realista: "Yo soy un escritor realista, porque creo que en America Latina todo es posible, todo es real” (MÁRQUEZ; LLOSA, 1968, p. 19), e mais adiante: "Vivimos rodeados de esas cosas extraordinarias y fantásticas y los escritores insisten en contarnos unas realidades inmediatas sin ninguna importância" (ibidem, p. 20); e depois reforça: "la irrealidad de la America Latina es una cosa tan real y tan cotidiana que está totalmente confundida con lo que se entiende por realidad" (ibidem, p. 40).

É importante destacar o que alertara Rama acerca do maravilhoso na América Latina, como não sendo algo específico do americano, embora seja "un elemento propio de ciertas zonas sociales" (RAMA, 1987, p. 237-8). Daí que o discurso de Márquez reflita a realidade com a qual viveu e, por isso, naturalizou, afinal "ningún escritor, absolutamente ninguno, inventa una obra, crea una construcción literaria en forma ajena al medio en el cual él nace, que al contrario, todo lo que puede hacer es trabajar un régimen de réplica" (RAMA, 1987, p. 151). Essa réplica, aliás, ficou bastante evidenciada quando na entrevista de Márquez a Vargas Llosa, aquele reconheceu que certos fatos e personagens de Cem anos de solidão teriam nascido de suas experiências pessoais: Úrsula, por exemplo, fora inspirada em uma tia do escritor. Tal fenômeno é também explicado por Ortega y Gasset, que "el hombre siempre, en cada instante, está viviendo según lo que es el mundo para él” (GASSET, 1983, p. 33).

Avaliando-se, porém, que essa narrativa de Gabriel García Márquez está repleta de intertextos de origem cristã-católica, é possível ainda admitir aqui um segundo ponto de vista, 
relacionado diretamente ao mito adâmico, em que Adão, ao despertar no Éden, e verificando que as coisas a que seus olhos punham atenção careciam de nome e significado, passou a nomeá-las: palavras virgens para coisas virgens. Nesse sentido, a construção “O mundo era tão recente que muitas coisas careciam de nome, e para mencioná-las era preciso apontar com o dedo" ganha uma nova leitura, por ser dual, como também acredita Ludmer (1972, p. 103): "El modelo de la oposición alternativa es siempre, en Cien años, la cumlinación de un juego dual de posibilidades narrativas". Assim, descortina outras possibilidades de análise. A narrativa, nesse caso, aponta para as estruturas duais ou, pelo menos, opostas, em um jogo discursivo e imagético permeado de inversões que põem em suspenção a lógica externa do leitor em paga da interna, própria das personagens, como se verá adiante. Aliás, a própria sucessão de nomes que se repetem e incorporam características comuns é um esforço do autor em empreender em sua narrativa esse ar de encantamento, inscrevendo-a no tempo mítico, circular, como observa Rama (1987, p. 215): "la elección de ciertos nombres y apellidos como Arcadio o Buendía, que se quiere reconstruir un tiempo no histórico sino legendario, un tiempo ajeno a la realidad".

\section{O jogo de inversões e oposições}

As operações que ocorrem na narrativa de Cem anos de solidão parecem construídas de modo a inverter o sentido de apreensão do leitor, aliás, desmontam o sentido da verossimilhança em detrimento de um atributo próprio do realismo maravilhoso. No primeiro capítulo do texto, por exemplo, Márquez explora a inversão dos sentidos ao apresentar objetos práticos como o ímã, a luneta, a lupa, o astrolábio, a bússola, a dentadura, por fim, o gelo, todos admitidos, pelo povo de Macondo - e assim explicados pelos ciganos -, como objetos mágicos, maravilhas de outro mundo. Nessa lógica, uma simples dentadura é vista como objeto de poderes sobrenaturais e encantatórios, capaz de rejuvenescer, em segundos, quem a utiliza:

Todo mundo foi até a tenda, e mediante o pagamento de um centavo todos viram Melquíades juvenil, reposto, desenrugado, com uma dentadura nova e radiante. Quem recordava suas gengivas destruídas pelo escorbuto, suas faces flácidas e seus lábios murchos, estremeceu de pavor diante daquela prova determinante dos poderes sobrenaturais do cigano (MÁRQUEZ, 2016, p. 14).

O procedimento utilizado por Márquez, porém, não é novo, e cumpre o seu papel na literariedade. É conhecido nos estudos literários como singularização, aqui em nível não de 
apreensão do leitor, mas de diegese, onde o narrador, apesar de nomear o objeto e apresentar as suas funções, representa o factual como algo novo, revolucionário. Dessa forma, o texto cumpre um objetivo: "dar a sensação do objeto como visão e não como reconhecimento" (CHKLOVSKI, 1973, p. 45), porque é do seu papel, como alertara Aristóteles em Poética, é próprio do seu discurso - língua poética, carregada de imagens -, possuir um caráter de suspensão, surpresa.

Se no procedimento anterior, Márquez singulariza a percepção de suas personagens, ou seja, o nível com que trabalha é o interno, no seguinte há o inverso, sua operação é externa: é o leitor quem, desta vez, sente a singularização do discurso. Assim, esse mesmo povo, estupefato com objetos comuns, parece aceitar com naturalidade ocorrências surreais ou sobrenaturais na narrativa, tais como a ascendência de Remédios, a Bela, aos céus, em carne e osso, ou mesmo a levitação do padre Nicanor, ocorrências que no campo da verossimilhança ou da automatização do discurso cotidiano são feridas em nome de outra lógica, a lógica do discurso poético, porque, "En Cien años de soledad todas las supersticiones y creencias populares se transforman en realidad" (LUDMER, 1972, p. 106-7) - diálogo esse bastante próximo ao discurso de Márquez ao ganhar o Nobel, ou seja, sua obra é, por essa ordem, uma espécie de alegoria da própria América Latina, em que o surreal é o que vem de fora e não o que existe em seus confins e história.

A observação desse ponto é o que permite definir a narrativa de Márquez como inscrita ao realismo maravilhoso, visto que, diferentemente do fantástico, aquele "desaloja qualquer efeito emotivo de calafrio, medo ou terror sobre o evento insólito. No seu lugar, coloca encantamento como um efeito discursivo pertinente à interpretação não-antitética dos componente diegéticos" (CHIAMPI, 2012, p. 59). Isso quer dizer que o evento deve estar reportado à diegese e às ações que nela se processam. Dessa forma, nesse tipo de narrativa, do ponto de vista das personagens, "não existe o impossível, nem o escândalo da razão" (ibidem, p. 60), o que permite, naturalmente, que eventos insólitos, do ângulo externo (ou seja, do leitor), sejam admitidos internamente (do ponto de vista das personagens) como coisas naturais. Daí "personagens do realismo maravilhoso [que] não se desconcertam jamais diante do sobrenatural, nem modalizam a natureza do acontecimento insólito" (ibidem, p. 61), afinal, "El hecho existe y no es puesto en duda" (LUDMER, 1972, p. 115).

Esse tipo de operação, como se tem dito, é invertido já no primeiro capítulo: o normal se torna insólito em paga deste, que se torna normal. Segundo Chiampi, essa técnica, porém, para configurar o realismo maravilhoso, deve vir atrelada a um efeito: o encantamento, que parece compassado ao entrelaçar justamente dos tempos histórico e mítico. Mais que isso: 
estruturalmente é possível reconhecer outros processos que ajudam a construir essa atmosfera de encantamento, em especial nos primeiros parágrafos, quando o narrador apresenta imagens, prototípicas dos contos de fadas, que remetem a tempos longínquos ao do tempo narrado. Assim é com Macondo, instalada à beira de um rio de águas diáfanas em cujo leito se precipita "pedras polidas, brancas e enormes como ovos pré-históricos" (MÁRQUEZ, 2016, p. 7, grifo nosso); ou ainda José Arcádio Buendía, que em posse de um ímã, à procura de ouro no leito desse mesmo rio, encontrara, na realidade, uma armadura do século XV e reforçando a aura mítica da narrativa -, após desmontar a armadura com a ajuda de quatro homens acha "dentro dela um esqueleto calcificado que levava dependurado no pescoço um relicário de cobre com um cacho de cabelo de mulher" (ibidem, p. 8). Foi essa característica que permitiu Ángel Rama reconhecer nas entrelinhas do romance uma vontade do narrador em remeter o texto sempre a um tempo pretérito, em que "Una cantidad de hechos contados en este comienzo de la novela, claramente marcan el afán del escritor por crear una Arcadia, un mundo pretérito anterior a la historia", cujas imagens vinculam-se "obviamente con todas las concepciones que las diversas leyendas y cosmogonías han hecho sobre los orígenes del mundo, el nacimieno de los hombres, y su establecimiento primero" (RAMA, 1987, p. 215).

Vê-se, pois, a construção de Macondo como isolada no meio do nada e sobre ela inúmeras imagens, de um minimundo, que vão se descortinando, a começar pelo primeiro elemento do mundo externo que penetra em seus confins: os ciganos, atraídos àquele meio do nada pelo canto de pássaros engaiolados, e seus objetos "maravilhosos". É o que ocorre, ainda, a José Arcádio Buendía, o homem mais empreendedor da aldeia, que em posse de alguns desses objetos, como astrolábio, bússola e sextante, certa vez, descobrira que a terra era redonda. $\mathrm{O}$ contraponto dessa descoberta, que já não era extraordinária ao mundo externo, é representado por sua esposa, Úrsula, que, em nível alegórico, por não acreditar no marido e desconfiada de sua maluquice -, representa o senso-comum que contrapõe desde tempos idos a própria ciência, considerando-a coisa do demônio e cujo remédio não era outro senão a reza. Mais uma vez Márquez se utiliza de um jogo de inversão ao construir essa imagem, posto ser a descoberta de José Arcádio Buendía vista com desconfiança e incredulidade pelo restante da população de Macondo, que não compreendia as suas teorias. Melquíades, o cigano que negociara os objetos necessários à descoberta de José Arcádio Buendía, foi quem, "exaltou em público a inteligência daquele homem que através de pura especulação astronômica havia construído uma teoria já comprovada na prática” (MÁRQUEZ, 2016, p. 11). Reconhecendo o mérito do "descobridor", Melquíades o presenteia com um laboratório de alquimia, outra imagem, também irônica, agora em oposição à figura daquele que parecia 
seguir os rumos da ciência e da objetividade e não da magia, tão mística. Um ciclo, pois, fechado, que o narrador, em imagens, faz notar: saído do sentimento místico, chega-se à razão, e uma vez nela, retorna-se ao afã originário do misticismo.

A alegoria que retrata a vontade de Macondo de entrar em contato com o mundo externo é problematizada em expedição com homens da aldeia. A fim de encontrar um caminho para o mar, José Arcádio Buendía, após enfrentar uma região encantada (primeiro elemento do realismo maravilhoso a aparecer na obra) - onde "os homens da expedição sentiram-se angustiados por recordações mais antigas naquele paraíso de umidade e silêncio, anterior ao pecado original", e ainda, "onde as botas afundavam em poços de óleo fumegante e os facões destroçavam lírios sangrentos e salamandras douradas" (ibidem, p. 18) -, e depara com um enorme galeão espanhol, cravado em um solo de pedras, a doze quilômetros do mar.

O contato com o mundo externo, advindo inicialmente dos ciganos, desperta em José Arcádio Buendía a primeira percepção de Macondo como isolada e a necessidade de vencer seus limites com o intuito de descobrir o que se passava além de suas terras: "Ali mesmo, do lado de lá do rio, existe tudo que é tipo de aparelho mágico, enquanto nós continuamos vivendo feito burros" (ibidem, p. 15). Esse início de processo de aculturação é completado quando sobre Macondo outros fluxos de contato com o meio externo vão locupletando a região, de modo que as suas características de rusticidade vão cedendo à instalação de repartições e instituições que dão um tom civilizatório ao espaço, agora admitido com ares de povoado.

\footnotetext{
De acanhada aldeia de outros tempos converteu-se depressa num povoado ativo, com lojas e oficinas de artesãos, e uma rota de comércio permanente através da qual chegaram os primeiros árabes de pantufas e argolas nas orelhas, trocando colares de vidro por araras e papagaios. José Arcádio Buendía não teve um instante de sossego. Fascinado por uma realidade imediata que acabou sendo mais fantástica que o vasto universo da sua imaginação (ibidem, p. 45).
}

Mais adiante, o narrador, cujo discurso, na concepção de Ludmer (1972, p. 108), é o de um historiador, "está situado por encima de los acontecimentos, conoce su desenlace", apresenta, na abertura do capítulo doze, a penetração dos aparelhos civilizatórios introduzidos em Macondo pelos filhos do coronel Aureliano Buendía, bem como o assombro constante de seus moradores frente às invenções e aparatos que passavam, de maneira centrípeta, a compor o dia a dia do povoado: "Varam a noite contemplando as lâmpadas elétricas alimentadas pela geradora que Aureliano Triste levara na segunda viagem do trem, e a cujo tum-tum obsessivo custou tempo e trabalho se acostumarem" (ibidem, p. 243). 
Assim é que, após o contato com os ciganos, Macondo assiste à chegada dos indígenas, imigrantes, instituições como escola, igreja, bar, correio, hotel, loja, culminando, ainda, com a destituição do aspecto pacifista, quando o coronel Aureliano Buendía engaja-se em guerras civis, e primitivo (sem a circulação de capital), quando chega a suas terras a industrialização, com a companhia bananeira. Aqui, o que poderia ser reconhecido como contraponto ou, antes, construção antitética entre o mundo externo e o mundo interno, se entrelaça, assim como o faz os tempos mítico e histórico. Há nessa transformação de Macondo certo paradoxo, quando analisado à luz das mudanças que se operam na figura de José Arcádio Buendía, cujo

Espírito de iniciativa social despareceu em pouco tempo, arrastado pela febre dos ímãs, dos cálculos astronômicos, dos sonhos de transmutação e das ânsias de conhecer as maravilhas do mundo. De empreendedor e limpo, [...] transformou-se num homem de aspecto folgazão, descuidado no vestir, com uma barba selvagem (ibidem, p. 16).

O narrador retrata a figura do cientista ou do estudioso desmilinguido porque afeito apenas às suas cogitações. E mais uma vez a inversão é caracterizada na narrativa: uma vez em posse das geringonças práticas e dos ganhos científicos advindos dos ciganos, José Arcádio Buendía, ao invés de atingir a razão, encontra uma perturbação mental, ou pelo menos assim é interpretado por seus pares, e acaba sendo amarrado a um tronco de árvore ao fundo do quintal de sua casa.

É válido atentar que a visão de encantamento na obra não reside apenas nas imagens que Márquez explora ao longo da narrativa, mas, como já dito, nas inversões que desmontam os acontecimentos insólitos que dão certo ar de conto de fadas ao texto. Assim, por volta da terceira ou da quarta incursão dos ciganos em Macondo, eis que estes apresentam ao povoado um tapete voador. A qualidade aérea do aparato não é vista com tanto vislumbre quanto os objetos práticos apresentados anteriormente, aliás, sua propriedade de levitação se transforma em acontecimento e diversão: "Uma tarde os rapazes se entusiasmaram com a esteira voadora que passou veloz ao nível da janela do laboratório levando o cigano piloto e várias crianças da aldeia que faziam alegres saudações com a mão" (ibidem, p. 39).

As oposições apresentadas até aqui são de ordem estética, dentro de um tempo mítico. Há, porém, em Cem anos de solidão, oposições que se desenvolvem ao longo de um tempo histórico. A narrativa, admitida como alegórica a uma história das próprias nações latinoamericanas, faz de Macondo uma terra cujo governo parece resistir ao revezamento entre conservadores e liberais. Doris Sommer também reconhece no livro uma construção 
tipicamente alegórica, no entanto, mais localista: "Ele narra o longo século da história atribulada da Colômbia, encenada como uma série de alianças eróticas entre famílias eminentes", e conclui: "Essas, porém, são famílias que lutam entre si, que confundem o interesse estrangeiro com mera curiosidade, e que resistem aos forasteiros talentosos, que o romance deveria ter incluído" (SOMMER, 2004, p. 44). Ludmer também compreende Cem anos de solidão como um romance "profundamente" político, "no solo en el sentido obvio (una toma de posición ferviente del lado del progresismo, por la acción, una versión política de la historia de Latinoamérica)", mas também "porque exhibe lo que debe ser ocultado, lo que en todos los sectores debe reprimirse (el trabajo empleado para producir, el sexo, la acción política y el riesgo de la muerte en la acción” (LUDMER, 1974, p. 154).

Como se pode depreender, na narrativa a ironia e a construção alegórica permitem que outra característica elementar surja, porque constituinte de seu modus operandi, ajudando a compreender o seu tecido: o uso de oposições, como bem identificou Josefina Ludmer, em sua análise estruturalista e, ainda, Ángel Rama, que em uma perspectiva mais aberta entende uma oscilação de polos no texto de Márquez, um centrípeto e outro centrífugo. Seria centrípeto, "Un polo que lleva el aniquilamiento por fragmentación y a la dispersión de material representado por los comportamientos de ciertos personajes que siempre están saliéndose, partiendo y desapareciendo del núcleo central” (RAMA, 1987, p. 224); e centrífugo, um "polo que es un esfuerzo de racionalización de la novela, de sistematización de los materiales, de planificación, representado por el esfuerzo de centrar la vida en torno a la casa y de mantener el funcionamiento de un núcleo" (ibídem, p. 224).

Nessa lógica, centrífugo seria o esforço do narrador em construir a imagem de Amaranta Úrsula sendo enviada para Bruxelas, porém, mais adiante, atraída a Macondo outra vez. O foco da narrativa, sem dúvida, é o povoado: todas as personagens, quando o deixam, desaparecem para o narrador. Amaranta Úrsula, por exemplo, reaparece e só então o narrador se ocupa com a sua existência. Assim, mundo interior e exterior são oposições que se desenham facilmente em Cem anos de solidão, apesar de haver entre eles certo entrelace, que vai desde a chegada de elementos externos à própria incorporação de hábitos e mudanças de conduta advindas desse contato.

Josefina Ludmer enxergou outras oposições operantes na obra, parte das quais reconhecidas ao longo da montagem da árvore genealógica dos Buendía. O exemplo dos dois casos de gêmeos que aparecem na família reflete bem a análise da estruturalista. Os primeiros gêmeos que surgem advindos do casal Remédios Moscote e coronel Aureliano Buendía, morrem atravessados no ventre da mãe, que também falece de hemorragia; diferentemente de 
Santa Sofia de la Piedad, casada com Arcádio, mãe dos gêmeos Aureliano Segundo e José Arcádio Segundo. A morte por hemorragia, como tudo que está amarrado na narrativa ${ }^{2}$, não ficou sem uma resposta na obra; mais adiante, será Amaranta Úrsula, após dar luz ao último rebento da estirpe Buendía, Aureliano, a morrer de hemorragia também. Daí que "los sintagmas narrativos son tres, compuesto cada uno de dos términos (gemelos, muerto hemorragia; gemelos, no muerte; cola de cerdo, muerte hemorragia" (LUDMER, 1972, p. 119).

A análise de Ludmer, porém, porque ocupada apenas com as gerações seguintes a Úrsula e José Arcádio, carece de uma visão sobre o que se poderia aqui denominar de "préhistória" da narrativa, de onde partem os vértices opostos que, às vezes, entrecruzam-se ao longo da árvore genealógica dos Buendía, construindo outros sintagmas. E é nessa busca pela pré-história do romance, os antecedentes de José Arcádio e Úrsula Iguarán, que a presente análise, no tópico seguinte, procurará entender a gênese dos mecanismos opostos que se operam em Cem anos de solidão.

\section{A pré-história do romance: uma breve contribuição}

Um dos pontos que não parece evidente, mas que ajuda a compreender uma série de circunstâncias na obra é a análise de sua pré-história, constituída a partir dos relatos dispersos do narrador ou dos próprios personagens e, por fim, na falta de lucidez de Úrsula Iguarán, o que não deixa de ser mais uma das ironias de García Márquez.

A montagem de uma árvore genealógica dos antepassados de José Arcádio Buendía e Úrsula Iguarán, por exemplo, permite analisar a origem espanhola da estirpe, no século XVI, e sua primeira relação com outra família, a aragonesa Iguarán, cujo entrelace resultará, mais adiante, na primeira relação parental entre homem e mulher, no século XIX.

A raiz, portanto, está no casal de imigrantes espanhóis que chega a Riohacha: Aureliano Arcádio Buendía e sua esposa, que não é identificada. Esse personagem, somente citado, é a origem mais remota de todas as gerações que se sucedem em Arcádios e Aurelianos. É seu filho, José Arcádio Buendía, quem primeiro resolve homenagear o pai, nomeando o filho de Aureliano Buendía, que se casa com a avó de Úrsula, Tranquilina. Daí em diante, o revezamento de nomes e de características próprias seguem linhas paralelas até

\footnotetext{
${ }^{2}$ A esse respeito, Ludmer (1972, p. 124) informa: “No hay, en Cien años, un número, una 'vez', un personaje, un acontecimiento, que no tenga su paralelo, su figura simétrica, siempre en un juego dual, formando parejas: este dato es demostrable en todos los niveles de la escritura".
} 
se entrelaçarem na $8^{a}$ geração (tomando como primeira a raiz aqui descrita), quando nascem os gêmeos Aureliano Segundo e José Arcádio Segundo. Nesse ponto, ambos não parecem admitir as mesmas características de seus nomes porque, ao que indica o narrador, as crianças foram, em algum momento, trocadas. Ou seja, Aureliano Segundo teria nascido sob o signo de José Arcádio Segundo; e este, daquele.

Não é esse, porém, o primeiro caso em que um José Arcádio e um Aureliano estão em um mesmo nível de descendência, coisa que não ocorre na pré-história, senão na composição unificada de Aureliano Arcádio Buendía. Ainda ao tomar este como primeira geração, é na sexta geração que surgirá em um mesmo nível um José Arcádio e um Aureliano que, a propósito, envolvem-se, na juventude, com uma mesma mulher: Pilar Ternera, deixando nela, cada um, um filho: Arcádio, para o primeiro, e Aureliano José, para o segundo. Essa ocorrência irá se repetir nas figuras dos gêmeos Aureliano Segundo e José Arcádio Segundo, netos de José Arcádio Buendía, que se envolvem também com uma mesma mulher, Petra Cotes, todavia, porque eram gêmeos e a mulher não os distinguia. Os netos de José Arcádio Buendía não seguem, porém, o destino do avô e do irmão do avô, pois não fecundam a amante em comum.

Há nesse jogo uma oposição, que à luz da árvore genealógica pré-histórica enceta alguma problemática quando da coexistência de Aurelianos e José Arcádios em um mesmo nível de descendência: o desfrutar de um mesmo gozo, não fugindo, pois, da unificação de seus espíritos como ocorrera na origem de toda estirpe Buendía, com Aureliano Arcádio. Essas foram as únicas vezes que a narrativa problematizou essa fusão por meio de um terceiro elemento, Pilar Ternera, no primeiro caso, e Petra Cotes, no segundo. Não há outros casos porque os demais Aurelianos e José Arcádios não estarão mais em um mesmo nível (ou grau) de descendência.

A visualização da pré-história, além disso, permite datar o tempo histórico da narrativa, apontando a origem dos Buendía em Riohacha no século XVI, como demonstra a abertura do segundo capítulo: "Quando o pirata Francis Drake assaltou Riohacha, no século XVI, a bisavó de Úrsula Iguarán se assustou tanto com o ressoar do sinal de alarme e o estampido dos canhões que perdeu o controle dos servos e sentou-se no fogão aceso" (MÁRQUEZ, 2016, p. 26). E é ainda nesse capítulo que Márquez dará o indício mais concreto do tempo em que estavam situados José Arcádio Buendía e Úrsula Iguarán. Após narrar o fato da bisavó de Úrsula, a narrativa comenta: 
Vários séculos mais tarde, o tataraneto do filho de imigrantes espanhóis casou-se com a tataraneta do aragonês. Por isso, cada vez que Úrsula saía dos eixos com as loucuras do marido, saltava por cima de trezentos anos de coincidências e amaldiçoava a hora em que Francis Drake assaltou Riohacha (ibidem, p. 26-7, grifo nosso).

A posteriori essa datação será confirmada pelo estudo de Ángel Rama acerca das demais obras do autor que dialogam entre si, especialmente La hojarasca em Cem anos de solidão. O pesquisador uruguaio se esforça em alocar a temporalidade da narrativa dentro do tempo histórico que se configura Cem anos de solidão: "Se extiende al año 1898, fundación de Macondo, a la guerra civil, probablemente por el año 1895, y aún a los tiempos de Aureliano Buendía" (RAMA, 1987, p. 175).

\section{A ocorrência e a persistência de elementos}

Em Cem anos de solidão há um jogo verbal de entrelinhas que serve de nó ao tecido narrativo: a ocorrência e a persistência de elementos que por si parecem narrar o desenrolar de fatos no enredo. A essa persistência, Ludmer (1972, p. 131) chama "similitude", em que "El narrador sitúa, en cada momento, la temporalidad particular del relatoy el punto preciso en que se coloca; retrocede para indicar coindicencias, similitudes y oposiciones". Márquez, em nível estrutural, apresenta sem nenhum temor, embora em alguns pontos com uma insistência reveladora, objetos ou ações que mais tarde ou denunciarão desfechos ou cumprirão seus destinos pré-revelados. É quando, por exemplo, demonstra no primeiro capítulo o modus operandi de Úrsula de esconder dinheiro enterrado debaixo de sua cama. A retomada desse tipo de ocorrência ajuda mais uma vez a construir sobre a narrativa de Márquez um caráter cíclico. Ou ainda quando confirma no casal uma preocupação com a saúde de sua estirpe, se nenhum dos filhos nasceria com algum rabo de porco ou órgão animal devido ao entrecruzamento de primos que estava na origem da família: Úrsula, para citar este caso, era prima legítima de José Arcádio Buendía, pois que tinha em comum com o marido o avô, como demonstra a árvore pré-histórica da narrativa, o primeiro Aureliano Buendía, que casara com Tranquilina Maria Miniata Alacoque. Há, nesse ponto, uma insistência do narrador em explorar o temor de uma estirpe de descendentes de um mesmo tronco: "Embora seu matrimônio fosse previsível desde que vieram ao mundo, quando expressaram a vontade de casar-se seus próprios parentes trataram de impedir", e o temor não era outro, mas o "de que aqueles saudáveis expoentes de duas raças seculares entrecruzadas passassem pela vergonha de engendrar iguanas" (MÁRQUEZ, 2016, p. 27). Mais ainda: haveria, já, na família, um caso 
antecedente, em que uma tia de Úrsula teve um filho "que morreu sangrando depois de haver vivido quarenta e dois anos no mais puro estado de virgindade, porque nasceu e cresceu com uma cauda cartilaginosa na forma de saca-rolha e com uma escovinha de pelos na ponta".

A morte desse primeiro parente, e até então único da estirpe a carregar um rabo de porco, ocorrera justamente em sua tentativa de extirpar o tal apêndice. Esse elemento, em Cem anos de solidão, é uma constante, principalmente na fala de Úrsula, a matriarca, que acompanha as mais diferentes gerações de Arcádios e Aurelianos na família. Torna a aparecer em Amaranta quando, em carícias eróticas com Aureliano José, luta por não se entregar ao sobrinho, pois que "os filhos nascem com rabo de porco" (ibidem, p. 164), mesmo frente aos pedidos insistentes do interlocutor: "Ela rejeitou-o com uma determinação inflexível, e passou para sempre a aldraba na porta do quarto" (ibidem, p. 165).

Essa preocupação constante culmina no último ente da família, que nasce com um rabo de porco, fruto do incesto de tia com sobrinho (Amaranta Úrsula e Aureliano Babilônia), o que põe fim à estirpe dos Buendía. Aliás, há, aqui, um jogo de oposição na árvore genealógica dos Buendía: ao se contar as gerações que viveram em Macondo, se a $2^{\mathrm{a}}$ e a $3^{\mathrm{a}}$ não consumam o ato (a tia Amaranta e o sobrinho Aureliano), o mesmo não ocorrerá às gerações $5^{\mathrm{a}}$ e $6^{\mathrm{a}}$, pois que o carma dos nomes persiste e leva ao ato incestuoso, exatamente entre tia (Amaranta Úrsula) e sobrinho (Aureliano Babilônia), logo, "En Cien años las máscaras están figuradas por los nombres" (LUDMER, 1972, p. 144). Há, portanto, no texto de Márquez, um caráter de retomada de elementos que persistem, e não por acaso ajudam a criar a perspectiva cíclica da narrativa, além de certo efeito de encantamento.

Nesse caso, outro parêntese merece ser aberto. A oposição que se constrói entre tia e sobrinho enceta ironia: se Úrsula é a personagem que mais alerta do perigo de envolvimento entre parentes, será justamente com a sua trineta, que carrega o seu nome, Amaranta Úrsula, que a tragédia se concretizará. Como se não bastasse, essa personagem carrega ainda o nome de sua tia-avó de $3^{\circ}$ grau, que ao envolver-se eroticamente com os sobrinhos, não indo além das felações por temor às consequências. Se em Cem anos de solidão a repetição dos nomes tem relação ainda com a transportação de características comuns, nesse ponto há uma antítese, em que o temor da primeira Amaranta e a prudência da primeira Úrsula, ao se unirem em um só corpo, o de Amaranta Úrsula, parecem se anular. E o elemento dessa anulação talvez resida na persistência de um terceiro elemento, Aureliano Babilônia, cujo sobrenome, que remete ao intertexto bíblico, faz jus à característica do aniquilamento e da maldição. É por força, é por insistência e teimosia do sobrinho que Amaranta Úrsula se entrega, apesar de ambos não terem ainda a noção do parentesco. O sangue, porém, como elemento irônico, dentro de uma 
perspectiva mítica da narrativa, busca essa consequência, por diversas vezes ensaiada mas até então nunca consumada.

Cem anos de solidão é construída dentro de uma estrutura fechada, como acredita Ludmer, e sem sombra de dúvidas cada elemento encontra conexão ou elo a partir de um terceiro elemento, como técnica que Márquez empregara a fim de dar ao texto um ar dual ou mesmo encantatório. Esse exercício contemporâneo de escrito é sintetizado por Ludmer (1972, p. 145) nos seguintes termos: "Similitud y alteración, reflejos y dobles, mismo y otro, paradoja, ironía, simetría, complementariedad", como operações de "un trabajo continuo de variaciones, multiplicaciones, fusiones, inversiones, sustituciones, metamorfosis y anamorfosis se opera en personajes, nombres, escenas, objetos, actores, parágrafos”.

Por fim, Úrsula, o elemento que une parte significativa da narrativa, emprestando ao texto certo significado, apesar de perder a lucidez, é quem, de maneira sensata, percebe as repetições que se operam na família. Por diversas vezes, ao observar as atitudes de Arcádios e Aurelianos, atenta para o óbvio: "É como se o tempo desse voltas redondas e tivéssemos voltado ao princípio" (MÁRQUEZ, 2016, p. 211). Assim, se o caráter cíclico de Cem anos de solidão se dá em nível externo, quando a narrativa por si só aponta para a sucessão de Aurelianos e de Arcádios, ele também ocorre internamente em Úrsula, a personagem que parece dividir com Pillar Ternera o foco narrativo.

A ironia, portanto, é o elo das relações que se operam na obra. Ela se liga à própria formação de Macondo que, vitimada por várias pragas, dentre as quais a do esquecimento e da insônia, é problematizada quando anos antes dessas ocorrências é José Arcádio Buendía quem, após a segunda leva de ciganos na aldeia - e que apresentam uma suposta máquina para esquecer as más lembranças -, deseja construir uma máquina não do esquecimento, mas da memória.

A análise de Cem anos de solidão não se esgota aqui. A correlação de seus intertextos a partir de técnicas de inversão e de oposição são ases que o escritor utiliza a fim de construir uma narrativa tipicamente moderna, cuja estrutura, apesar de cerrada (como acredita Ludmer), enceta, na flutuação dos níveis interno e externo, uma leitura dual e plurissignificativa, quando avaliada ainda a construção alegórica do texto, cujo projeto parece vislumbrar uma teia de acontecimentos que, ao tempo que edificam a narrativa, se consomem ao longo das sobreposições de gerações dos Buendía.

\section{Referências}


ANÔNIMO. Popol-vuh: o libro del consejo de los indios quichés. Tradução do francês de Miguel Ángel Asturias e J. M. González de Mendonza. México: Instituto Cultural Quetzalcoatl de Antropología Psicoanalítica. Disponível em: <http://www.samaelgnosis.net/sagrados/pdf/popol_vuh.pdf>. Acesso em 27 mai. 2017.

CHIAMPI, Irlemar. O realismo maravilhoso: forma e ideologia no romance hispanoamericano. São Paulo: Perspectiva, 2012.

CHKLOVSKI, V. A arte como procedimento. In: TOLEDO, Dionísio de Oliveira. Teoria da literatura: formalistas russos. Tradução de Ana Mariza Ribeiro Filipouski et al. Porto Alegre: Editora Globo, 1973. p. 39-56.

ELIADE, Mircea. Mito do eterno retorno. Tradução de José A. Ceschin. São Paulo: Mercuryo, 1992.

GASSET, Ortega y. La idea de la generación. In: . Obras completas. Madrid: Alianza Editorial, Revista de Occidente, 1983, vol. 5. p. 29-42.

LUDMER, Josefina. Modo de construir el discurso narrativo. In: Cien años de soledad: una interpretación. Argentina: Editorial Tiempo Contemporáneo, 1972. p. 99-156.

MÁRQUEZ, Gabriel García. Cem anos de solidão. 93. ed. Tradução de Eric Napomuceno. Rio de Janeiro: Record, 2016.

MÁRQUEZ, Gabriel García; LLOSA, Mário Vargas. La novela em américa latina: dialogo. Lima: Universidad Nacional de Ingenieria, 1968.

MÁRQUEZ, Gabriel García. A solidão da América Latina. RevIU, Foz do Iguaçu, v. 2, n. 1, p. 12-14, 2014.

RAMA, Ángel. La narrativa de Gabriel García Márquez: edificación de um arte nacional y popular. Montevideo: Universidad de la República, Faculdad de Humanidades y Ciencias, 1987.

SOMMER, Doris. Ficções de fundação: os romances nacionais da América Latina. Tradução de Gláucia Renate Gonçalves e Eliana Lourenço de Lima Reis. Belo Horizonte: UFMG, 2004. 